\title{
Methods to Quantify Reactive Chromium Vaporization from Solid Oxide Fuel Cell Interconnects
}

\author{
C. Key, ${ }^{a, z}$ J. Eziashi, ${ }^{b, *}$ J. Froitzheim,,${ }^{c, * *}$ R. Amendola, ${ }^{d,}{ }^{* *}$ R. Smith, ${ }^{a}$ and P. Gannon ${ }^{b, * *}$ \\ ${ }^{a}$ Physics, University of Texas Brownsville, Cavalry Building, Brownsville, Texas 78521, USA \\ ${ }^{b}$ Chemical Engineering, Montana State University-Bozeman, Cobleigh Hall, Bozeman, Montana 59717, USA \\ ${ }^{c}$ High Temperature Corrosion Centre, Chalmers University of Technology, Göteborg 41296, Sweden \\ ${ }^{d}$ Mechanical and Industrial Engineering, Montana State University, Roberts Hall, Bozeman, Montana 59717, USA
}

High-temperature $\left(>600^{\circ} \mathrm{C}\right.$ ) reactive vaporization of $\mathrm{Cr}$ from chromia and stainless steels in oxidizing environments is an industrially relevant phenomenon that has been and will continue to be studied extensively for decades. Recently, many experimental techniques have been developed to measure $\mathrm{Cr}$ vaporization from stainless steel interconnect (IC) components within solid oxide fuel cell (SOFC) systems. Many of these techniques are based on an experimental method known as the transpiration method, which is used to generate $\mathrm{Cr}$ vapors and subsequently collect them for quantitative analysis. However, vapor collection and analysis methods differ significantly between investigators within the community, as does the array of alloys (with and without protective surface coatings), temperatures, flow rates, and water vapor pressures used in experimentation. Therefore, the purpose of the present work is to provide an overview of experimental techniques used to quantify reactive $\mathrm{Cr}$ vaporization, and to compare data reported in literature on $\mathrm{Cr}$ vaporization from $\mathrm{Cr}_{2} \mathrm{O}_{3}$ and chromium containing alloys in oxidizing environments.

(C) The Author(s) 2014. Published by ECS. This is an open access article distributed under the terms of the Creative Commons Attribution 4.0 License (CC BY, http://creativecommons.org/licenses/by/4.0/), which permits unrestricted reuse of the work in any medium, provided the original work is properly cited. [DOI: 10.1149/2.0041409jes] All rights reserved.

Manuscript submitted February 25, 2014; revised manuscript received May 12, 2014. Published May 23, 2014.

Advances in materials development and production methods significantly extend the operating temperature range of SOFCs toward progressively lower and lower temperatures. This broadens the spectrum of materials that can be used to fabricate cell components as well as structure/balance of plant components, greatly reducing costs. One such example pertains to cell interconnects (ICs). ICs serve to electrically connect individual electrochemical cells in series and parallel to an external load. They also physically separate fuel gas from oxidant and therefore must be impermeable (hermetic) and chemically stable in both environments. Although electronically conductive ceramic ICs have demonstrated stable performance in high temperature $\left(900-1000^{\circ} \mathrm{C}\right)$ SOFC systems, they are particularly cost prohibitive. ${ }^{1,2}$ At temperatures less than $900^{\circ} \mathrm{C}$, ferritic stainless steels meet many of the material requirements associated with cell interconnection: high conductivity, good mechanical strength, thermal expansion properties that match other SOFC components, and manufacturability at low cost. ${ }^{3}$ However, long-term stability of steel in oxidizing and reducing environments remains a significant technological challenge, largely due to reactive $\mathrm{Cr}$ vaporization. ${ }^{4}$

High temperature corrosion resistance exhibited by ferritic steel (containing over $15 \mathrm{wt} \% \mathrm{Cr}$ ) in oxidizing environments is attributed to the formation of a thin, passivating chromia $\left(\mathrm{Cr}_{2} \mathrm{O}_{3}\right)$ scale on the surface of the metal. ${ }^{5,6}$ Under operating conditions of the SOFC cathode, chromia reacts with oxygen and water vapor producing gaseous $\mathrm{Cr}$ vapors, ${ }^{5-8}$ depleting $\mathrm{Cr}$ in the alloy and, most importantly, poisoning the cell by depositing $\mathrm{Cr}$ around the cathode/electrolyte interface. ${ }^{9-14}$

Many varieties of alloys, shown in Table I, and protective coatings have been developed to help mitigate $\mathrm{Cr}$ vaporization. Research efforts have focused on perovskite or spinel structure coatings using techniques such as physical vapor deposition (PVD), thermal spraying or dip coating. ${ }^{4,13}$ In order to gauge the effectiveness of a coating or steel it is necessary to measure the amount of $\mathrm{Cr}$ vapor released at SOFC operating temperatures, thus a branch of experimental techniques has emerged to quantify $\mathrm{Cr}$ vaporization. ${ }^{21-24}$ The standard approach, known as the transpiration method, enables measurement of chromium vapors in the presence of high concentrations of other gases. ${ }^{25}$ Recently, other collection techniques have arisen to avoid some of the challenges posed by the standard transpiration method. The goal of this paper is to: (i) review the basic operating principles of the transpiration method (ii) summarize thermodynamic equilibrium

\footnotetext{
*Electrochemical Society Student Member.

*** Electrochemical Society Active Member.

${ }^{\text {z} E-m a i l: ~ c k e y @ p h y s . u t b . e d u ~}$
}

measurements of $\mathrm{Cr}$ vapor species in oxidizing environments; (iii) present unique $\mathrm{Cr}$ collection/analysis techniques; and, (iv) compare available non-equilibrium $\mathrm{Cr}$ vaporization rate data from candidate IC alloys and coatings.

\section{Background}

Hexavalent $\mathrm{Cr}$ is a well-known carcinogen, ${ }^{26}$ especially in the gaseous phase. Investigators should be prudent with exhausted vapors and avoid contact with $\mathrm{Cr}(\mathrm{VI})$ in the condensed phase.

The transpiration method.- There are many ways to study high temperature vaporization processes. The Knudsen effusion method has been used extensively to study thermodynamic properties of vapors and solids in equilibrium, yet is only applicable when vapor pressures are less than $1 \mathrm{~Pa}\left(10^{-5} \mathrm{~atm}\right) .^{27,28}$ Vapors at higher pressures can be measured through static pressure measurements, but are of limited use when multiple gas species are present. For this reason, the transpiration method, also known as the transportation or entrainment method, has become one of the most popular ways to study $\mathrm{Cr}$ vaporization from SOFC-ICs. ${ }^{4,13,14,16,22}$ The method has been used since the mid-1800s to study vapor pressures, dissociation pressures, gas/solid and gas/liquid equilibria from a wide variety of material systems, ${ }^{25}$ and is ideal for measurements performed at atmospheric pressure with small concentrations of $\mathrm{Cr}$ vapors in the reactant gas.

Detailed theoretical descriptions by Merten and Wahlbeck outline how to use the transpiration method to establish equilibrium vapor pressures of gaseous species at high temperatures. ${ }^{25,29}$ A simplified version of the experimental apparatus can be seen in Figure 1, where samples are heated to the desired temperature within a furnace. A stream of carrier or reactant gas is introduced into the reactor allowing physical dissociation processes or chemical reactions to occur at the gas/solid interface. Volatile species are transported downstream with the flow and collected for subsequent analysis. Figure 2 presents the experimental setup developed at the Institute for Materials and Processes in Energy Systems in Juelich, Germany and illustrates the design complexity that arises when accurate data on gaseous species are desired. For the purpose of the experimental portion of this review, discussion will include how temperature, water vapor pressures and flow rates are regulated.

Temperature control.-Temperature measurement and control is paramount in any vaporization study. Modern furnaces enable high precision temperature control, which can vary depending upon the 
Table I. Chemical compositions of alloys used in $\mathrm{Cr}$ vaporization studies.

Concentration (wt $\%)$

\begin{tabular}{|c|c|c|c|c|c|c|c|c|c|c|c|c|c|}
\hline \multirow[b]{2}{*}{ Alloy } & & & & & & & & & & & & & \multirow[b]{2}{*}{ Ref. } \\
\hline & $\mathrm{Fe}$ & $\mathrm{Cr}$ & $\mathrm{Si}$ & $\mathrm{Mn}$ & $\mathrm{Ni}$ & $\mathrm{Al}$ & $\mathrm{Ti}$ & $\mathrm{Y}$ & Mo & $\mathrm{C}$ & $\mathrm{N}$ & other & \\
\hline Crofer 22 APU & bal & 22.7 & 0.02 & 0.38 & 0.02 & 0.02 & 0.07 & - & - & 0.002 & 0.004 & La: 0.06 & 4,15 \\
\hline E-Brite & bal & $24-26$ & $0.003-0.2$ & 0.05 & 0.15 & - & - & - & 0.96 & 0.01 & 0.004 & - & 15,16 \\
\hline Ducrolloy & 5.5 & bal & - & - & - & - & - & 0.5 & - & 0.01 & 0.014 & - & 15 \\
\hline $\mathrm{Cr} 5 \mathrm{Fe} 1 \mathrm{Y}_{2} \mathrm{O}_{3}$ & 5 & bal & - & - & - & - & - & 1 & - & - & - & - & 14 \\
\hline $446 \mathrm{SS}$ & bal & 25.6 & - & 0.41 & 0.3 & - & - & - & - & - & 0.18 & - & 17 \\
\hline Sanergy HT & bal & 21.2 & 0.12 & 0.3 & - & 0.02 & 0.09 & - & 0.96 & 0.04 & - & $\mathrm{Nb}: 0.71$ & 4 \\
\hline $430 \mathrm{SS}$ & bal & 16 & 0.3 & 0.9 & 0.08 & 0.14 & - & - & - & 0.07 & - & P: 0.28 & 18 \\
\hline ZGM 232 & bal & 22 & 0.4 & 0.45 & 0.29 & 0.18 & - & - & - & 0.024 & 0.005 & Zr: 0.13 & 15 \\
\hline ZGM 232 G10 & bal & 23.7 & 0.02 & 0.28 & - & - & - & - & - & - & - & $\begin{array}{c}\text { W: } 1.4, \mathrm{Cu}: \\
0.93\end{array}$ & 19 \\
\hline Haynes 230 & 3 & 22 & 0.4 & 0.5 & 52.7 & 0.3 & - & - & 2 & 0.1 & - & $\begin{array}{c}\text { W: } 14, \text { Co: } 5 \text {, } \\
\text { B: } 0.015, \\
\text { Ce/La: } 0.02\end{array}$ & 16 \\
\hline $441 \mathrm{SS}$ & bal & 18 & 0.34 & 0.35 & 0.3 & 0.05 & 0.22 & - & - & 0.01 & 0.014 & $\begin{array}{c}\mathrm{Nb}: 0.5, \mathrm{P}: \\
0.02\end{array}$ & 16 \\
\hline RA600 & 8 & 15.5 & 0.2 & 0.1 & bal & - & - & - & - & 0.08 & - & - & 20 \\
\hline RA446 & bal & $23-27$ & 1 & 1.5 & - & - & - & - & - & 0.2 & 0.12 & - & 20 \\
\hline
\end{tabular}

type of temperature sensor used. Temperatures must be measured in the exact sample region to be accurate, and for practical purposes, thermocouples are often utilized. Chromel-alumel or K-type thermal couples are somewhat ubiquitous because of how inexpensive they are and the wide range of temperatures they can measure. They are limited however, to a precision of $\pm 0.0075 \times \mathrm{T}$ from $333^{\circ} \mathrm{C}-1200^{\circ} \mathrm{C} .{ }^{30}$ Another important issue is that bare wires readily oxidize in air at at-

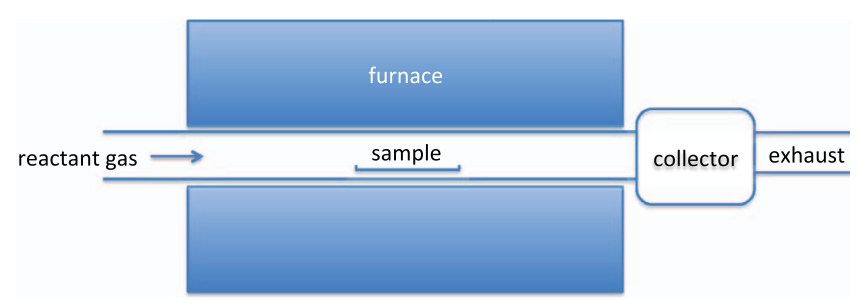

Figure 1. Schematic of a transpiration apparatus. mospheric pressure and can be a source of $\mathrm{Cr}$ vapor in the experiment. Inert sheathing of thermocouple wires is available and drastically reduces the impact of oxidation, making k-type thermocouples a viable option for use in experiment, so long as the degree of precision and oxidation concerns are accounted for. Platinum and ruthenium thermocouples provide a significantly higher degree of corrosion resistance and improved precision over k-type, $\pm 0.0025 \times \mathrm{T}$ between $600^{\circ} \mathrm{C}$ and $1700^{\circ} \mathrm{C} .^{30}$ However, oxidation of sheathed noble metal thermocouples has been reported in humid oxidizing environments above $1300^{\circ} \mathrm{C}$, causing erroneous temperature readings over time. ${ }^{7}$

One other consideration in temperature control is the presence of thermal gradients within the reaction zone. In high temperature furnaces, temperature variations of several degrees can occur over short distances. Flow restrictors placed above and below the sample region help provide a well-insulated region that is uniform in temperature. They also aid in bringing the incoming gas stream up to temperature preventing non-uniform sample cooling at high flow rates. Vapor condensation on downstream flow restrictors is a potential concern but has not been reported in literature for $\mathrm{Cr}$ vapors. Condensation on

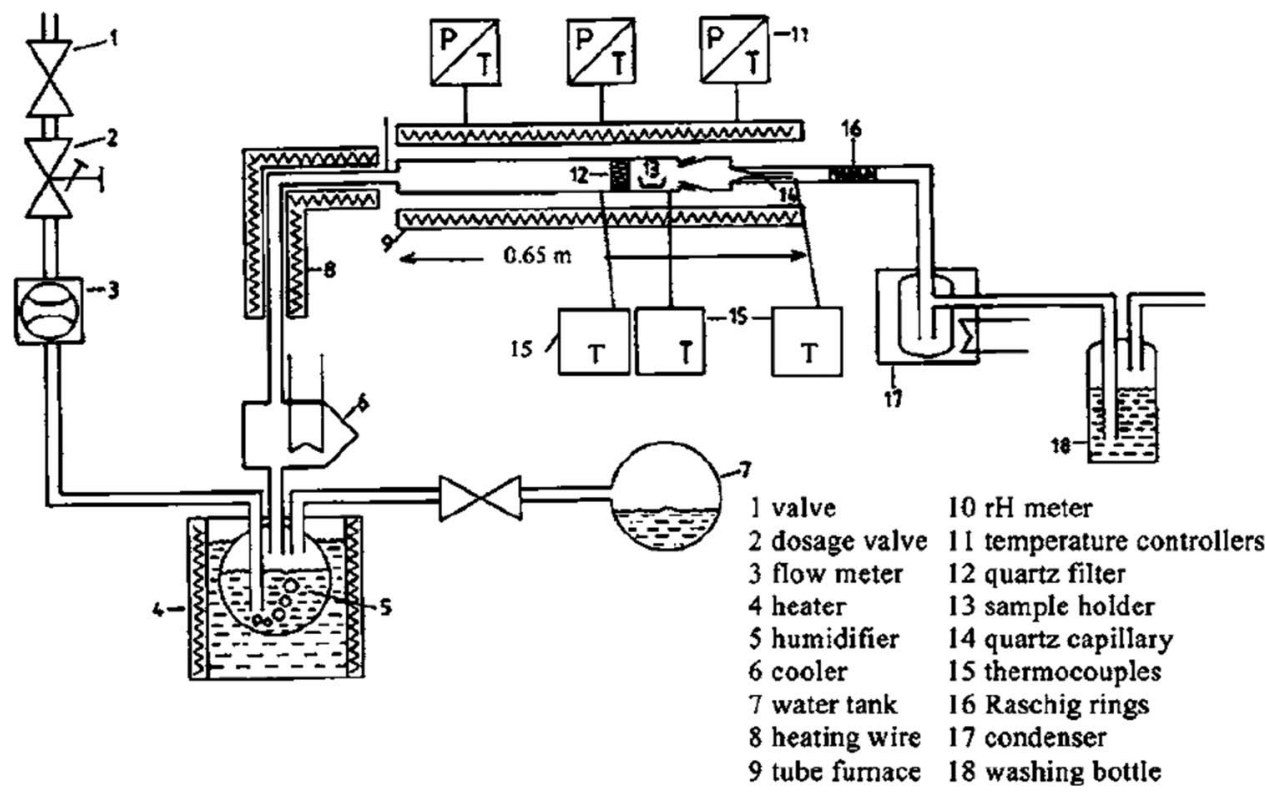

Figure 2. Experimental design of the transpiration apparatus at the Juelich Research Center. ${ }^{15}$ 


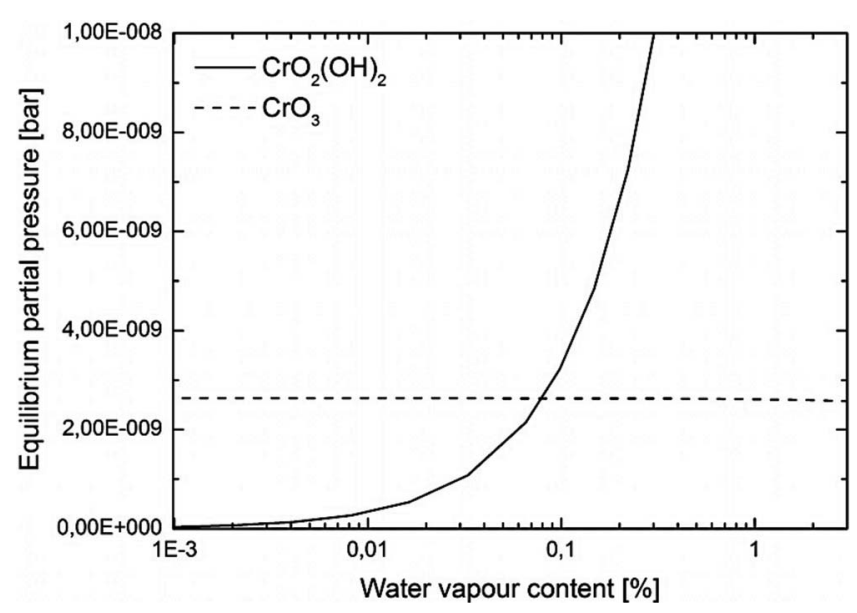

Figure 3. Partial pressures of $\mathrm{CrO}_{3}$ and $\mathrm{CrO}_{2}(\mathrm{OH})_{2}$ over $\mathrm{Cr}_{2} \mathrm{O}_{3}(\mathrm{~s})$ in air at $800^{\circ} \mathrm{C}$ as a function of water vapor pressure based on thermodynamic data from Opila and Ebbinghaus. ${ }^{33}$

downstream flow restrictors can be avoided by maintaining them at a higher temperature than the sample region.

Water vapor pressure.-Cr vaporization rates in oxidizing environments depend strongly upon the amount of water vapor in the reactant gas stream ${ }^{31,32}$ as demonstrated in Figure 3. Care must therefore be taken to precisely control water vapor pressure during experimentation. Two distinct methods to control water vapor pressure have been employed: water vapor injection through the use of a peristaltic pump $^{34,35}$ and bubbling gas flow through temperature-controlled gaswashing bottles. ${ }^{13}$ In both cases, tubing downstream from the water vapor source must be maintained at a high enough temperature to prevent unwanted condensation. Gas-washing bottles should to be used in conjunction with a condensing unit for precise control over water vapor pressure.

Flow rates.-In a transpiration experiment, the vaporization rate of a material depends upon reactant gas flow rates. Flow rate data are commonly reported in literature as volumetric flow rates $\left(\mathrm{L} \mathrm{s}^{-1}\right)$, making their interpretation difficult when information about the reactor's diameter is not given. A much more useful measure is the linear gas velocity of the flow through the reactor, ${ }^{32}$ since this value is independent of the reactor's cross-sectional area.

To illustrate how flow rates affect vaporization, the mass transport rate, $\mathrm{k}_{\mathrm{Cr}}\left(\mathrm{kg} \mathrm{s}^{-1}\right.$ or moles $\mathrm{s}^{-1}$ ), of $\mathrm{Cr}$ vapor is graphed versus flow rate in Figure 4. Five distinct flow regimes are shown in the figure, which have been demonstrated experimentally. ${ }^{13,36}$ Region A corresponds to measurements made at very little or no flow, where diffusion

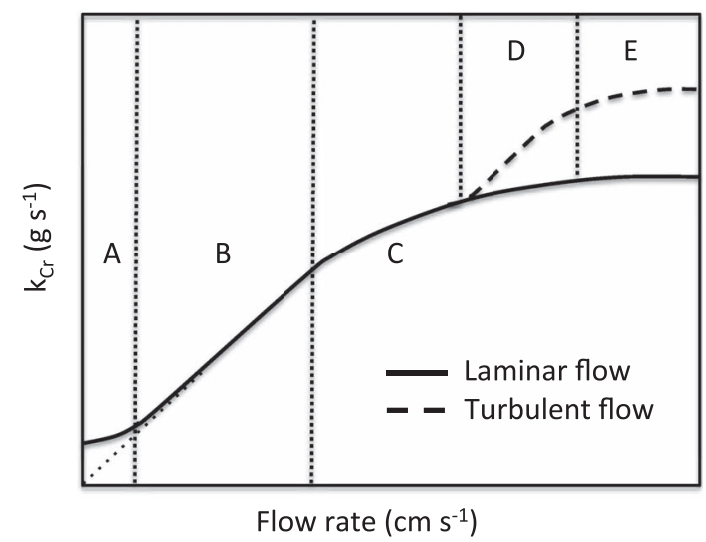

Figure 4. Vaporization rate versus flow rate curve depicting laminar flow regimes: (A) diffusion dominated, (B) equilibrium and (C) unsaturated; and two turbulent flows regimes: (D) and (E).

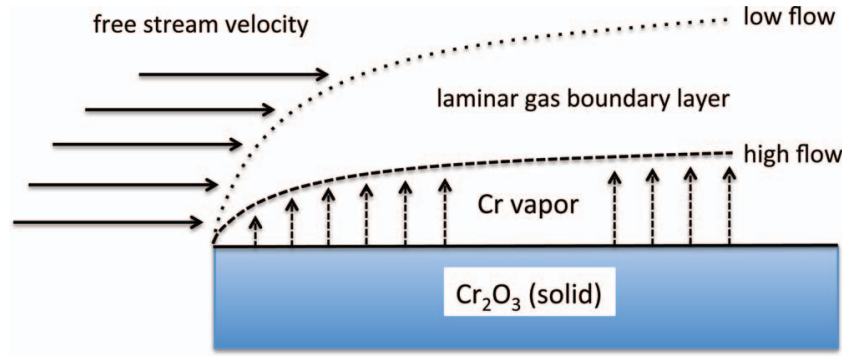

Figure 5. Laminar gas boundary layer above a flat $\mathrm{Cr}_{2} \mathrm{O}_{3}$ surface at low and high flow rates.

dominates $\mathrm{Cr}$ vapor transport to the collector. When the flow rate is increased, bulk flow becomes the primary source of vapor transport. Region B in Figure 4 depicts bulk transport, where a linear increase in the amount of $\mathrm{Cr}$ collected versus flow rate is characteristic of thermodynamic equilibrium between the sample and the gas flow. ${ }^{37}$

At higher flow rates, kinetic limitations cause the $\mathrm{Cr}$ transport rate to plateau as shown in region $\mathrm{C}$ of Figure 4. Graham and Davis have reported that mass transport of $\mathrm{Cr}$ vapor across a laminar gas boundary layer is the rate-limiting step for $\mathrm{CrO}_{3}(\mathrm{~g})$ production (see Reaction 2 in the subsequent section). ${ }^{38} \mathrm{Cr}$ vaporization studies on IC alloys are commonly performed in this regime to replicate SOFC flow conditions. Figure 5 depicts the boundary layer thickness for low and high flows. At high flow rates $\mathrm{Cr}$ vapors cannot fully diffuse into the free stream, resulting in a gas mixture that is unsaturated in $\mathrm{Cr}$ vapor. Stanislowski et al. suggest that further increase in the $\mathrm{Cr}$ transport rate occurs at the onset of turbulent flow shown by region D of Figure $4 .{ }^{13}$ Again, transport rates plateau, region $\mathrm{E}$, due to incomplete mixing of $\mathrm{Cr}$ vapor into the turbulent gas flow.

Experimental design dictates the range of flow rates that define a particular flow regime. The size of samples plays a major role in this regard. Different investigators often test samples of different thicknesses and shapes, resulting in different values for the $\mathrm{Cr}$ transport rate at a given flow rate. For this reason, vaporization rates, defined as the transport rate per unit sample area $\left(\mathrm{kg} \mathrm{m}^{-2} \mathrm{~s}^{-1}\right)$ or mass $\left(\mathrm{kg} \mathrm{g}^{-1} \mathrm{~s}^{-1}\right)$, are useful and often reported in literature. Vaporization rates reported in graphical form, as is commonly the case, should also be presented in a table to aid other investigators.

$\mathrm{Cr}_{2} \mathrm{O}_{3}-\mathrm{O}_{2}-\mathrm{H}_{2} \mathrm{O}$ interactions at $\mathrm{SOFC}$ operating temperatures.An extensive study by Ebbinghaus ${ }^{39}$ presents the thermodynamics of gas phase chromium species over $\mathrm{Cr}_{2} \mathrm{O}_{3}$ (s) in humid oxidizing environments. Figure 6 illustrates Ebbinghaus' data at $800^{\circ} \mathrm{C}$ with $3 \%$

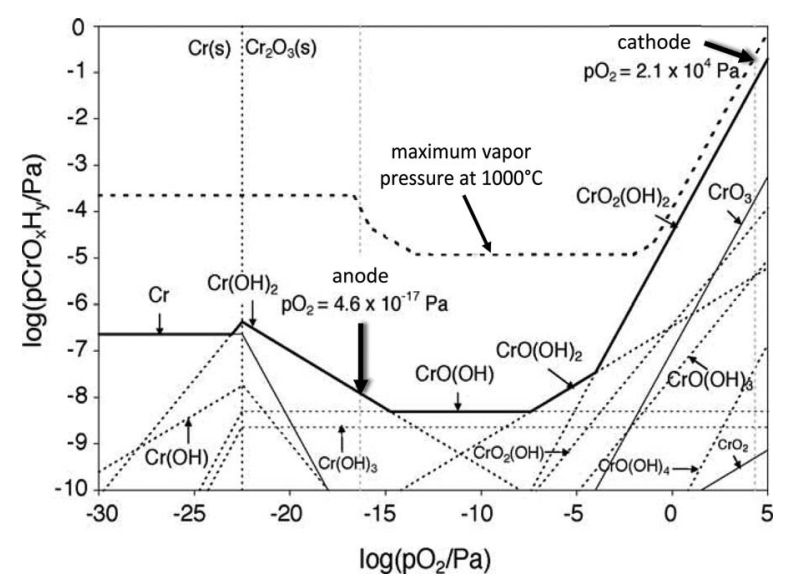

Figure 6. Equilibrium vapor pressures of chromium-oxygen-hydrogen gas species at $800^{\circ} \mathrm{C}$ with $3 \% \mathrm{H}_{2} \mathrm{O}$ based on thermodynamic database from Ebbinghaus. The maximum vapor pressure for all $\mathrm{Cr}$ species at $1000^{\circ} \mathrm{C}$ is indicated by the bold dashed line. Reproduced with permission from the Journal of Materials Science and Engineering A. ${ }^{40}$ 


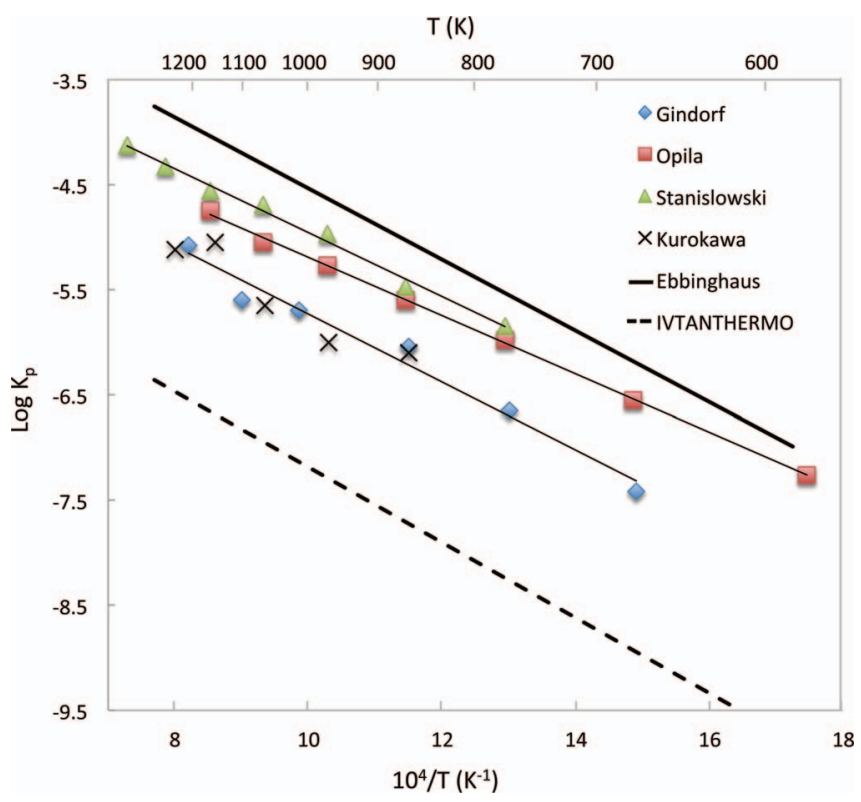

Figure 7. Temperature dependence of the equilibrium constant, $\mathrm{K}_{\mathrm{p}}$, for the reaction $\frac{1}{2} \mathrm{Cr}_{2} \mathrm{O}_{3}(\mathrm{~s})+\frac{3}{4} \mathrm{O}_{2}(\mathrm{~g})+\mathrm{H}_{2} \mathrm{O}(\mathrm{g})=\mathrm{CrO}_{2}(\mathrm{OH})_{2}(\mathrm{~g})$ based on experimental data of Gindorf, ${ }^{31}$ Opila, ${ }^{34}$ Stanislowski, ${ }^{15}$ Kurokawa, ${ }^{9}$ and thermodynamic data compiled by Ebbinghaus ${ }^{39}$ and Russian database IVTANTHERMO. ${ }^{43}$

water vapor as a function of oxygen partial pressure..$^{40}$ Oxygen partial pressures representative of SOFC cathodic and anodic environments are indicated by bold arrows at $\mathrm{pO}_{2}=2.1 \times 10^{4} \mathrm{~Pa}$ and $\mathrm{pO}_{2}=4.6$ $\times 10^{-17} \mathrm{~Pa}$ respectively. The cathode side $\left(\mathrm{pO}_{2}=2.1 \times 10^{4} \mathrm{~Pa}\right)$ is the most deleterious for SOFCs with ferritic steel ICs since $\mathrm{Cr}$ vapor pressures are highest. The bold dashed line in Figure 6 represents the combined partial pressure of all $\mathrm{Cr}$ vapor species at $1000^{\circ} \mathrm{C}$ and indicates that $\mathrm{Cr}$ vapor pressures remain high at $800^{\circ} \mathrm{C}$ in the cathode environment when compared to the anode. Thus, $\mathrm{Cr}$ vaporization will still be an issue with ferritic stainless steel ICs, even when the SOFC operating temperature is reduced to $650^{\circ} \mathrm{C} .{ }^{41}$

As reported in literature, $\mathrm{CrO}_{2}(\mathrm{OH})_{2}, \mathrm{CrO}_{3}$, and $\mathrm{CrO}_{2}(\mathrm{OH})$ are the most abundant vapor species in high oxygen partial pressure environments when water vapor is present. ${ }^{8,39,42}$ The involved chemical reactions can be seen in Equations 1-3 below.

$$
\begin{array}{r}
\frac{1}{2} \mathrm{Cr}_{2} \mathrm{O}_{3}(\mathrm{~s})+\mathrm{H}_{2} \mathrm{O}(\mathrm{g})+\frac{3}{4} \mathrm{O}_{2}(\mathrm{~g}) \mathrm{CrO}_{2}(\mathrm{OH})_{2}(\mathrm{~g}) \\
\frac{1}{2} \mathrm{Cr}_{2} \mathrm{O}_{3}(\mathrm{~s})+\frac{3}{4} \mathrm{O}_{2}(\mathrm{~g})=\mathrm{CrO}_{3}(\mathrm{~g}) \\
\frac{1}{2} \mathrm{Cr}_{2} \mathrm{O}_{3}(\mathrm{~s})+\frac{1}{2} \mathrm{H}_{2} \mathrm{O}(\mathrm{g})+\frac{1}{2} \mathrm{O}_{2}(\mathrm{~g})=\mathrm{CrO}_{2}(\mathrm{OH})(\mathrm{g})
\end{array}
$$

At typical SOFC operating temperatures reaction 1 is the most relevant when water vapor is present. This is illustrated in Figure 3 which, based on thermodynamic data from Opila ${ }^{34}$ and Ebbinghaus, ${ }^{39}$ shows water vapor pressure dependence of $\mathrm{CrO}_{2}(\mathrm{OH})_{2}(\mathrm{~g})$ and $\mathrm{CrO}_{3}(\mathrm{~g})$ in air at $800^{\circ} \mathrm{C}$. When $\mathrm{p}\left(\mathrm{H}_{2} \mathrm{O}\right)$ exceeds $1 \times 10^{2} \mathrm{~Pa}(0.1 \%), \mathrm{CrO}_{2}(\mathrm{OH})_{2}(\mathrm{~g})$ becomes the most dominant vapor species.

Figure 7, adopted from Stanislowski, et al. ${ }^{13}$ shows order-ofmagnitude discrepancies in the temperature dependence of the equilibrium rate constant, $\mathrm{K}_{\mathrm{p}}$, for Reaction 1. Experimental data from Gindorf, Opila, and Stanislowski suggest a lower rate constant than Ebbinghaus and completely rule out IVTANTHERMO ${ }^{43}$ data on $\mathrm{CrO}_{2}(\mathrm{OH})_{2}$. A linear fit of experimental data can be interpreted through the following relation

$$
\ln \mathrm{K}_{\mathrm{p}}=-\frac{\Delta \mathrm{H}_{r}^{\mathrm{o}}}{\mathrm{R}}\left(\frac{1}{\mathrm{~T}}\right)+\frac{\Delta \mathrm{S}_{r}^{\mathrm{o}}}{\mathrm{R}}
$$

and allows second law determination of the enthalpy change, $\Delta \mathrm{H}_{r}^{\mathrm{o}}$, and the entropy change, $\Delta \mathrm{S}_{r}^{\mathrm{o}}$, for the reaction. ${ }^{44}$ Note that the vertical axis in Figure 7 is expressed as $\log \mathrm{K}_{\mathrm{p}}$ and differs from Equation 4 by a factor of $\log (\mathrm{e})$. The equilibrium rate constant for Reaction 1 is given by

$$
\mathrm{K}_{\mathrm{p}}=\frac{\mathrm{p}_{\mathrm{CrO}_{2}(\mathrm{OH})_{2}}}{\left(\mathrm{a}_{\mathrm{Cr}_{2} \mathrm{O}_{3}}\right)^{0.5}\left(\mathrm{X}_{\mathrm{H}_{2} \mathrm{O}} \mathrm{P}_{\text {tot }}\right)\left(\mathrm{X}_{\mathrm{O}_{2}} \mathrm{P}_{\text {tot }}\right)^{0.75}}
$$

where $\mathrm{X}$ is the mole fraction of the designated gas species, and $\mathrm{a}_{\mathrm{Cr}_{2} \mathrm{O}_{3}}$ is the activity of chromia (equal to one for pure chromia). The partial pressure of $\mathrm{CrO}_{2}(\mathrm{OH})_{2}$

$$
\mathrm{p}_{\mathrm{CrO}_{2}(\mathrm{OH})_{2}}=\frac{\mathrm{n}_{\mathrm{CrO}_{2}(\mathrm{OH})_{2}}}{\mathrm{n}_{\mathrm{tot}}} \mathrm{P}_{\mathrm{tot}}
$$

is obtained from experiment by measuring the number of moles of collected $\mathrm{Cr}, \mathrm{n}_{\mathrm{CrO}_{2}(\mathrm{OH})_{2}}$, the total number of moles of gas, $\mathrm{n}_{\text {tot }}$, that passed through the transpiration apparatus; and the experimental pressure, $\mathrm{P}_{\text {tot }}$.

Two criteria must be met to obtain reliable thermodynamic data using a transpiration experiment: flow rates must be governed such that they lie in the equilibrium flow regime, region B in Figure 4; and there must only be one known $\mathrm{Cr}$ vapor phase present, since $\mathrm{K}_{\mathrm{p}}$ depends uniquely on the reaction equation. Opila et al. offer a very comprehensive equilibrium vapor pressure study of Reaction 1, and along with the work of Stanislowski et al., improve upon Ebbinghaus' data.

Kim and Belton investigated Equation 2 between $1324^{\circ} \mathrm{C}$ and $1583^{\circ} \mathrm{C}^{7}$ Their data are the basis for Ebbinghaus' thermodynamic functions for $\mathrm{CrO}_{3}(\mathrm{~g})$ after he made minor corrections for the small amount of $\mathrm{CrO}_{2}(\mathrm{~g})$ present at these temperatures. Opila experimentally determined one value for the equilibrium rate constant for Reaction 2 at $900^{\circ} \mathrm{C}$ which matches well with Kim and Belton's data. ${ }^{34}$

Kim and Belton also carried out measurements on $\mathrm{Cr}_{2} \mathrm{O}_{3}(\mathrm{~s})$ in oxygen and water vapor between $1299^{\circ} \mathrm{C}$ and $1525^{\circ} \mathrm{C}^{7}$ to establish the equilibrium rate constant and standard Gibbs free energy change for $\mathrm{CrO}_{2}(\mathrm{OH})$ vapor, Reaction 3. Their findings were not supported by Ebbinghaus on account of the high vapor pressure Ebbinghaus calculated for $\mathrm{CrO}_{2}(\mathrm{OH})_{2}$ in this temperature range. Opila and Stanislowski's measurements however, suggest a lower vapor pressure for $\mathrm{CrO}_{2}(\mathrm{OH})_{2}$ than Ebbinghaus, which helps reinforce Kim and Belton's results. Additionally, Opila reanalyzed Kim and Belton's work and determined, based upon water vapor and oxygen partial pressure dependence of $\mathrm{Cr}$ vapor species, that their results are consistent with $\mathrm{CrO}_{2}(\mathrm{OH})$ as the primary vapor phase in the temperature range of the study. ${ }^{34}$

\section{Vapor Collection and Analysis Techniques}

The ultimate precision of the transpiration method depends upon experimental collection efficiency, and the type of quantitative analysis used. Table II provides a summary of collection efficiencies and analytical precision for the techniques described in following portion of this review. Sample size and experiment duration can be increased to overcome limitations of a particular technique.

Mass change.- The simplest way to quantify vaporization of a material is to measure its change in mass as a function of time. Kim and Belton used this method for $\mathrm{Cr}_{2} \mathrm{O}_{3}$ vaporization studies above $1300^{\circ} \mathrm{C}$, by manually weighing specimens before and after heating. They were able to detect changes in mass on the order of $20 \times 10 \mu \mathrm{g}$ and attributed all mass change to $\mathrm{Cr}$ vaporization, since no weight gain was expected in the oxide. ${ }^{7}$ The same assumption cannot be made for ferritic stainless steels because of oxide scale growth. Weight change, for a material that gains mass as it oxidizes and simultaneously loses mass though vaporization processes, is described by paralinear kinetics. ${ }^{32}$ Thermogravimetric analysis (TGA) has been used in this capacity to study steel alloys and was performed in conjunction with mass spectrometry (TGA-MS) by Pérez-Trujillo and Castañeda to identify $\mathrm{Cr}$ vapor species. ${ }^{47}$ TGA has also been employed in transpiration studies 
Table II. Summary of analytic techniques used to quantify $\mathrm{Cr}$ vapors.

\begin{tabular}{ccccc} 
Technique & Efficiency & Analysis Method & Detection Limit & Information \\
\hline Mass Loss & $100 \%$ & Mass Balance & $1 \mathrm{ppm}$ & Total Cr \\
TGA-MS & $100 \%$ & TGA-MS & $100 \mathrm{ppb}$ & Total Cr, Cr species and other elements \\
Condensation & Assumes $100 \%$ & ICP-MS & $1-0.01^{45} \mathrm{ppb}$ & Total Cr and other elements \\
Condensation & Assumes 100\% & ICP-AES & $3 \mathrm{ppb}^{46}$ & Total Cr and other elements \\
Quartz Wool & $80 \%$ & ICP-MS & $1-0.01^{45} \mathrm{ppb}$ & Total Cr and other elements \\
Ceramic Plate & na & EDS & $100 \mathrm{ppm}$ & Relative Cr and other elements \\
Wafer Collector & $10 \%$ & RBS & $1 \mathrm{ppm}$ & Relative Cr and other elements \\
Denuder & $95 \pm 5 \%$ & Photospectrometry & Total Cr \\
ICM & $100 \%$ & Conductivity Probe & $10 \mathrm{ppm}$ & Total Cr
\end{tabular}

to measure equilibrium vapor pressures of solids, ${ }^{36}$ but there is no reference in the literature for its use on equilibrium measurements for the $\mathrm{Cr}_{2} \mathrm{O}_{3}-\mathrm{O}_{2}-\mathrm{H}_{2} \mathrm{O}$ system.

Traditional condensation-based collector- - The traditional condensation collector functions by condensing $\mathrm{Cr}$ vapors in fused quartz tubing or in a quartz condensation cell as they exit the hot furnace, as shown in Figure 2. $\mathrm{Cr}$ is removed from the quartz through a series of highly concentrated $\mathrm{HCl}$ and $\mathrm{HF}$ acid washes. To ensure complete $\mathrm{Cr}$ collection, vapors are exhausted through a water bath (refer to Figure 2, item 18) and all components downstream from the tested samples are washed. $\mathrm{Cr}$ content in the resulting solutions is subsequently determined by chemical analysis and is equivalent to the total amount of chromium vaporized during the experiment. Although individual measurements only quantify total $\mathrm{Cr}$, experiments consisting of multiple measurements can be designed to identify the most abundant molecular species produced in the reactor.

Opila et al. identified two types of $\mathrm{Cr}$ deposits in quartz collection tubes: chromic acid, $\mathrm{CrO}_{2}(\mathrm{OH})_{2}$; and chromia $\mathrm{Cr}_{2} \mathrm{O}_{3}(\mathrm{~s})$. At temperatures of $600^{\circ} \mathrm{C}$ and below chromic acid was deposited as a brown liquid, but was also found in solid form on the walls of the tubing. Green chromia deposits were also noticed on tube walls upstream from chromic acid deposits at temperatures between $700^{\circ} \mathrm{C}$ and $900^{\circ} \mathrm{C}$, and were very difficult to remove. ${ }^{34}$

Two types of chemical analyzes have been reportedly used in traditional transpiration based studies: inductively coupled plasma-mass spectrometry ${ }^{13}$ (ICP-MS) and inductively coupled plasma-atomic emission spectrometry ${ }^{32}$ (ICP-AES). Both types of analyzes utilize the ICP, where a tiny amount of test solution is nebulized and passes through argon plasma. In this process, molecules in solution are atomized and ionized. When mass spectrometry is used, ionic constituents are separated according to their charge-to-mass ratios and measured to determine elemental concentrations. AES measures the wavelength and intensity of light emitted from excited electrons as they transition back to their ground state. The wavelength of emitted light identifies individual elements in the solution, while the intensity of emission at a particular wavelength gives elemental concentrations. ICP-MS has a lower detection limit than ICP-AES, ${ }^{45}$ Table II. However, ICP-MS analyzes can be significantly impacted by the presence of ionic species with similar charge to mass ratios. Konysheva et al. identify ${ }^{35} \mathrm{Cl}^{16} \mathrm{O}^{+}$, ${ }^{37} \mathrm{Cl}^{16} \mathrm{O}^{+}$, and ${ }^{35} \mathrm{Cl}^{16} \mathrm{O}^{1} \mathrm{H}^{+}$as the primary source of interference with ionic $\mathrm{Cr}$ species but such interferences can be corrected. ${ }^{14}$

Traditional condensation-based collection of $\mathrm{Cr}$ vapor has been used by multiple research groups in the field ${ }^{13,14,31,34}$ to measure $\mathrm{Cr}$ vaporization rates from chromium containing alloys, coated alloys and pure chromia samples. Measurements performed on steels are taken at non-equilibrium (unsaturated) flow rates, where small differences in flow do not impact the overall vaporization rate. Vaporization rates from tested alloys are compared in Table III. Rates are reported over well-defined intervals of testing, and uniformly indicate that $\mathrm{Cr}$ vaporization rates are highest during the initial stages of high temperature exposure, while the chromia scale is forming. Several alloys have been tested by multiple experimenters and arrive at similar values for $\mathrm{Cr}$ vaporization rates. Accurate evaluation of vaporized $\mathrm{Cr}$ re- quires highly concentrated acid rinses to remove condensed $\mathrm{Cr}$ from quartz surfaces, making complete $\mathrm{Cr}$ collection and analysis difficult. Kurokawa avoided this step by ultrasonically washing tubes in DI water alone and reported appreciable amounts of collected $\mathrm{Cr}^{9}{ }^{9}$

Quartz wool collector- - An adaptation of the traditional condensation method under development at Montana State University (MSU) utilizes high surface-area quartz wool to collect volatile $\mathrm{Cr}$ species. Figure 8 shows the exhaust end of a transpiration experiment, where $\mathrm{Cr}$ collection is evident by discoloration in the quartz wool. $\mathrm{Cr}$ is removed from the wool by ultrasonic rinsing in dilute nitric acid and prepared in solutions. The total mass of $\mathrm{Cr}$ collected is then determined by ICP-MS analysis.

The technique has only recently been developed, but vaporization rate comparisons with Froitzheim et al. ${ }^{48}$ have yielded promising results, as seen in Table III. Measurements indicate that $\mathrm{Cr}$ primarily deposits in quartz wool below $200^{\circ} \mathrm{C}$ (near the $196^{\circ} \mathrm{C}$ melting point of chromic acid) ${ }^{53}$ and supports the findings of Opila et al. that $\mathrm{CrO}_{2}(\mathrm{OH})_{2}$ vapor species predominantly condense congruently as $\mathrm{CrO}_{2}(\mathrm{OH})_{2}$ (s). At temperatures below $60^{\circ} \mathrm{C}$ (corresponding to water vapor condensation) $\mathrm{Cr}$ deposits turned from dark brown to yellow, attributeable to dissolution of $\mathrm{CrO}_{2}(\mathrm{OH})_{2}$ into $\mathrm{CrO}_{4}{ }^{-2}$. Solubility of $\mathrm{CrO}_{2}(\mathrm{OH})_{2}$ in water has been noted and is discussed in the ionic conductivity method subsection. At temperatures around $500^{\circ} \mathrm{C}$ small amounts of green chromia $\left(\mathrm{Cr}_{2} \mathrm{O}_{3}\right)$ were found to condense on tube walls. Similar observations were again reported by Opila et al. ${ }^{32}$ Green deposits were minimal for experiments where exhausted gases cooled through a less severe temperature gradient from the furnace to ambient temperatures.

Ceramic plate collector- - Figure 9 illustrates a relatively simple technique for qualitative assessment of $\mathrm{Cr}$ volatility by analyzing condensate on ceramic collectors. The technique involves enclosing the test material within ceramic plates (e.g. alumina plates). Reactant gas is passed across the samples to generate $\mathrm{Cr}$ vapors. A significant proportion of chromium that vaporizes from the sample collects on the ceramic plates creating a visible stain. Energy Dispersive X-ray Spectroscopy (EDS) is used to analyze the amount of $\mathrm{Cr}$ that deposits on the plates. This technique is meant to be a quick, easy and inexpensive way of screening candidate materials, without being fully quantitative. Researchers at Hitachi Metals, Ltd. used this method to access $\mathrm{Cr}$ vaporization from ferritic stainless steels for SOFC-IC applications, and found a correlation between $\mathrm{Mn}$ content and $\mathrm{Cr}$ vaporization. ZGM232L with $0.46 \mathrm{wt} \% \mathrm{Mn}$ showed lower $\mathrm{Cr}$ vaporization rates than alloys with less than $0.2 \mathrm{wt} \% \mathrm{Mn}$, due to the formation of a thicker Mn spinel surface scale. The study also found that additions of $\mathrm{Cu}$, from $0.94 \mathrm{wt} \%$ to $1.44 \mathrm{wt} \%$, reduced $\mathrm{Cr}$ vaporization in alloys containing $0.30 \mathrm{wt} \% \mathrm{Mn}$ and helped limit growth of the Mn spinel layer. ${ }^{24}$ However, Sachitanand et al. also studied ZMG 232 G10 steel with $\mathrm{Cu}$ additions using the denuder technique described below, but could not reproduce the beneficial effect of $\mathrm{Cu}$ on $\mathrm{Cr}$ vaporization. ${ }^{19}$

Silicon wafer collector- - Another variant to the standard condensation method uses ion-beam analysis to measure the amount of $\mathrm{Cr}$ 
Table III. Cr vaporization rates $\left(\mathrm{kg} \mathrm{m}^{-2} \mathrm{~s}^{-1}\right)$ from coated and uncoated SOFC-ICs. Water vapor pressures are given as partial pressures, $\mathrm{p}\left(\mathrm{H}_{2} \mathrm{O}\right)$. Most data are obtained in high flow regimes although there is some variation in gas velocity for the different studies. Furthermore, it should be noted that $\mathrm{Cr}$ vaporization rates are not constant over time for most materials. Thus, ranges of values are shown where experimenters collected data over multiple time intervals, with initial vaporization rates written first.

\begin{tabular}{|c|c|c|c|c|c|}
\hline Investigator & Alloy/Coating & Temp & Carrier Gas & $\mathrm{p}\left(\mathrm{H}_{2} \mathrm{O}\right)$ & $\begin{array}{l}\text { Vaporization Rate* } \\
\left(10^{-10} \mathrm{~kg} \mathrm{~m}^{-2} \mathrm{~s}^{-1}\right)\end{array}$ \\
\hline \multirow{9}{*}{$\begin{array}{l}\text { Stanislowski et al. }{ }^{13} \\
\text { (condensation cell) }\end{array}$} & Crofer 22 APU & $800^{\circ} \mathrm{C}$ & air & 0.0188 & $5-2$ \\
\hline & Crofer 22 APU/LSC-80 & & & & $6-5$ \\
\hline & Crofer 22 APU/LMAC-DLR & & & & $4-1$ \\
\hline & Crofer $22 \mathrm{APU} / \mathrm{Co}$ & & & & $0.01-0.005$ \\
\hline & Crofer $22 \mathrm{APU} / \mathrm{Cu}$ & & & & $0.03-0.01$ \\
\hline & Crofer 22 APU/Ni & & & & 0.01 \\
\hline & E-Brite & & & & $7-6$ \\
\hline & E-Brite/Co & & & & 0.03 \\
\hline & Ducrolloy & & & & 6 \\
\hline \multirow{8}{*}{$\begin{array}{l}\text { Konysheva et al. }{ }^{14} \\
\text { (condensation cell) }\end{array}$} & Crofer 22 APU & $900^{\circ} \mathrm{C}$ & air & 0.019 & 3 \\
\hline & & $850^{\circ} \mathrm{C}$ & & & 2 \\
\hline & & $800^{\circ} \mathrm{C}$ & & & $2-1$ \\
\hline & & $750^{\circ} \mathrm{C}$ & & & 0.8 \\
\hline & $\mathrm{Cr} 5 \mathrm{Fe} 1 \mathrm{Y}_{2} \mathrm{O}_{3}$ & $900^{\circ} \mathrm{C}$ & & & $10-9$ \\
\hline & & $850^{\circ} \mathrm{C}$ & & & 7 \\
\hline & & $800^{\circ} \mathrm{C}$ & & & $6-5$ \\
\hline & & $750^{\circ} \mathrm{C}$ & & & 3 \\
\hline \multirow{4}{*}{$\begin{array}{l}\text { Chatterjee et al. }{ }^{49} \\
\text { (condensation cell) }\end{array}$} & $446 \mathrm{SS}$ & $800^{\circ} \mathrm{C}$ & air & 0.02 & 4 \\
\hline & & $750^{\circ} \mathrm{C}$ & & & 3 \\
\hline & & $700^{\circ} \mathrm{C}$ & & & 1 \\
\hline & E-brite & $700^{\circ} \mathrm{C}$ & & & 2 \\
\hline \multirow{2}{*}{$\begin{array}{l}\text { MSU HT materials research } \\
\text { group }^{50} \text { (quartz wool collector) }\end{array}$} & Crofer 22 APU & $850^{\circ} \mathrm{C}$ & air & 0.023 & $6-2$ \\
\hline & Sanergy HT & (ex-situ temp) & & & $9-5$ \\
\hline \multirow{3}{*}{$\begin{array}{c}\text { Collins et al. }{ }^{22} \text { (Si wafer } \\
\text { collector) }\end{array}$} & Crofer 22 APU & $800^{\circ} \mathrm{C}$ & air & $\sim 0.03$ & $0.6-0.3$ \\
\hline & $430 \mathrm{SS}$ & (ex-situ temp) & & & $0.7-0.4$ \\
\hline & $430 \mathrm{SS} / \mathrm{CoMnO}$ & & & & 0.2 \\
\hline \multirow{2}{*}{$\begin{array}{l}\text { Chen et al. }{ }^{51} \text { (Si wafer } \\
\text { collector) }\end{array}$} & $430 \mathrm{SS}$ & $800^{\circ} \mathrm{C}$ & air & 0.167 & $3-2$ \\
\hline & $430 \mathrm{SS} / \mathrm{TiCrAlYO}(1.6 \mu \mathrm{m})$ & (ex-situ temp) & & & $0.2-0.02$ \\
\hline \multirow[t]{5}{*}{ Froitzheim et al. ${ }^{48}$ (denuder) } & Crofer 22 APU & $850^{\circ} \mathrm{C}$ & air & 0.03 & $8-4$ \\
\hline & Crofer 22 APU/La ceram $(50 \mu \mathrm{m})$ & & & & 1 \\
\hline & Sanergy HT & & & & $11-9$ \\
\hline & Sanergy HT/Co(640 nm) & & & & 1 \\
\hline & ZGM 232 & & & & $8-6$ \\
\hline \multirow[t]{4}{*}{ Sachitanand et al..$^{19}$ (denuder) } & Crofer 22 APU & $850^{\circ} \mathrm{C}$ & air & 0.03 & $6-4$ \\
\hline & E-Brite & & & & $22-21$ \\
\hline & Sanergy HT & & & & $9-7$ \\
\hline & ZGM 232 G10 & & & & $11-9$ \\
\hline Grolig et al. ${ }^{52}$ (denuder) & $441 \mathrm{SS}$ & $850^{\circ} \mathrm{C}$ & air & 0.03 & 8 \\
\hline \multirow[t]{4}{*}{ Windisch et al..$^{41}$ (denuder) } & Crofer 22 APU & $750^{\circ} \mathrm{C}$ & air & 0.03 & $8-2$ \\
\hline & Sanergy HT & $850^{\circ} \mathrm{C}$ & & & $21-6$ \\
\hline & Sanergy HT & $750^{\circ} \mathrm{C}$ & & & $7-5$ \\
\hline & Sanergy HT & $650^{\circ} \mathrm{C}$ & & & 3 \\
\hline \multirow[t]{6}{*}{ Casteel et al. ${ }^{16}$ (ICM) } & Crofer 22 APU & $800^{\circ} \mathrm{C}$ & air & 0.077 & 1.6 \\
\hline & E-Brite & & & 0.074 & 2.5 \\
\hline & ZGM 232 & & & & 0.5 \\
\hline & Haynes 230 & & & & 1.8 \\
\hline & $441 \mathrm{SS}$ & & & 0.069 & 2.5 \\
\hline & Chromia Pellet & & & 0.074 & 5 \\
\hline
\end{tabular}

collected on Si wafers during an experiment. Figure 10 shows two Si wafers affixed via carbon tape to a water-cooled heat sink. The heat sink is placed in the effluent gas stream, and vapors condense on the surface of the wafers. Wafers are removed and analyzed using Rutherford backscattering spectroscopy (RBS) to quantify $\mathrm{Cr}$ collection. Figure 11 illustrates a characteristic RBS spectrum of Cr collected on a Si wafer. Since the Rutherford cross-section of $\mathrm{Cr}$ is known, the area under the $\mathrm{Cr}$ peak is directly proportional to the areal density of $\mathrm{Cr}$ atoms (atoms/unit area) on the Si surface. The method is therefore quantitative without the need for calibration or standards.
Unlike traditional condensation-based methods, this technique facilitates the determination of $\mathrm{Cr}$ release as a function of time, since wafers can be removed and replaced with new ones without interrupting an experiment. Vaporization rates can be resolved on a minimum time scale of 5-10 hours depending upon Cr release rates from individual samples. An added benefit to this approach is that the elemental identity of vapor species evolving from a sample can be rapidly identified and quantified with one measurement, since each elemental species condensed on the wafer surface appears as a peak in the RBS spectrum. 


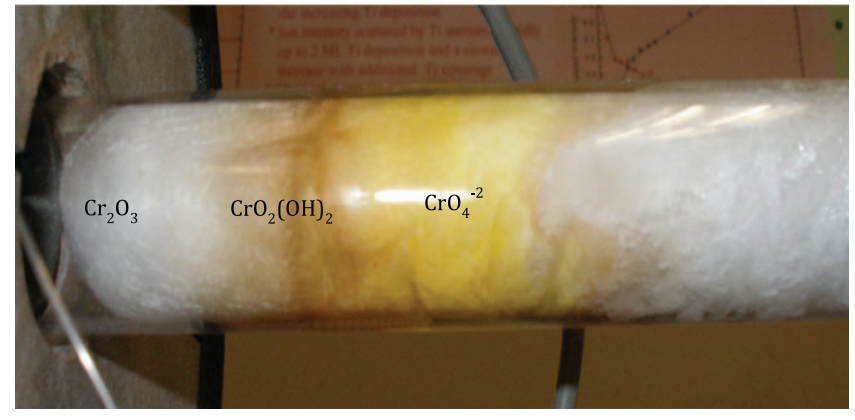

Figure 8. Quartz wool collector with three phases of $\mathrm{Cr}$ present: $\mathrm{Cr}_{2} \mathrm{O}_{3}$ forming around $500^{\circ} \mathrm{C}$ (not visible in photograph), $\mathrm{CrO}_{2}(\mathrm{OH})_{2}$ condensing at $200^{\circ} \mathrm{C}$, and $\mathrm{CrO}_{4}{ }^{-2}$ dissolved in condensed water below $60^{\circ} \mathrm{C}$.
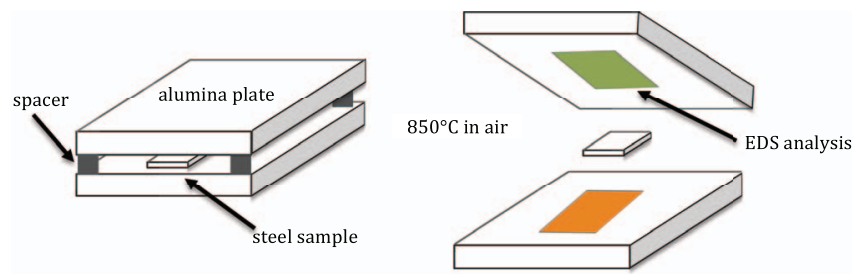

Figure 9. Ceramic plate staining technique. ${ }^{24}$

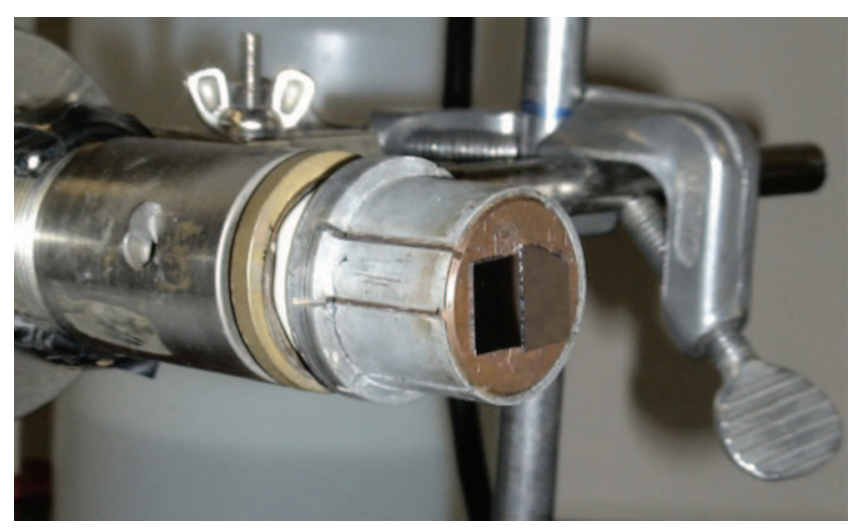

Figure 10. Silicon wafer collectors mounted on a water cooled copper sink.

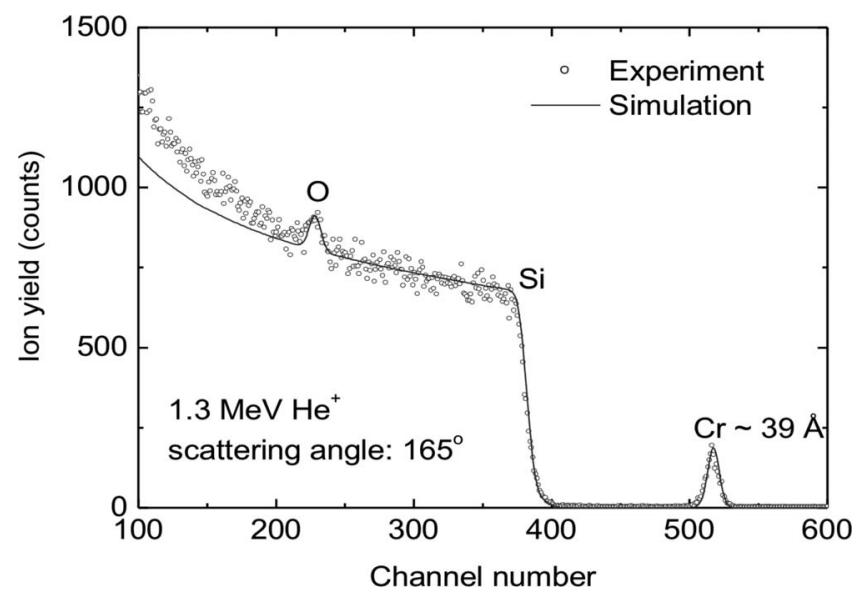

Figure 11. RBS data showing chromium collected on a Si wafer. ${ }^{51}$
RBS requires access to a particle accelerator for analysis, creating an obstacle for its adoption by most researchers. Other analytical tools can be used in place of RBS, but lack the quantitative benefit the technique provides. Additionally, several variables dictate collection efficiency: collection wafer temperature, wafer roughness/composition (glassy carbon wafers have also been used) and flow characteristics at the wafer's surface. Low collection efficiency, as illustrated by comparison with other collection techniques in Table III, makes it challenging to access the absolute vaporization rate of a material. Despite that downside, the method has been used successfully to compare relative vaporization rates between alloys and coated alloys.

Denuder technique.- Vapor collection in small capillaries, known as denuder tubes, has been used to study a wide variety of vapor species. A mathematical treatment of the denuder technique may be found in work by Gormley and Kennedy, ${ }^{54}$ and Ali et al. ${ }^{55}$ Reactive coatings on the inner surfaces of denuder tubes help facilitate vapor collection and analysis when compared to traditional condensation methods.

Figure 12 shows the denuder-based transpiration experiment developed at Chalmers University of Technology, Sweden, which employs sodium carbonate $\left(\mathrm{Na}_{2} \mathrm{CO}_{3}\right)$ coatings for chromium collection through the following reaction:

$$
\mathrm{CrO}_{2}(\mathrm{OH})_{2}(\mathrm{~g})+\mathrm{Na}_{2} \mathrm{CO}_{3}(\mathrm{~s}) \rightarrow \mathrm{Na}_{2} \mathrm{CrO}_{4}(\mathrm{~s})+\mathrm{H}_{2} \mathrm{O}(\mathrm{g})+\mathrm{CO}_{2}(\mathrm{~g}) \text {. }
$$

The reaction product, sodium chromate $\left(\mathrm{Na}_{2} \mathrm{CrO}_{4}\right)$, is watersoluble and can be easily rinsed from quartz tubing. Photospectrometry or ICP-MS analysis performed on the resulting solutions provides quantification of the total amount of vaporized chromium. Measurements comparing the mass change of chromia $\left(\mathrm{Cr}_{2} \mathrm{O}_{3}\right)$ pellets to the amount of $\mathrm{Cr}$ collected in denuder tubes demonstrate $95 \pm 5 \%$ collection efficiency. ${ }^{4}$ Based upon the stated collection efficiency, this technique offers accuracy comparable to the best condensation methods, and eliminates the need to remove $\mathrm{Cr}$ from glassware using highly concentrated acids. Furthermore, similar to the silicon wafer technique and ionic conductivity method (discussed below), data can be acquired without disturbing the experiment allowing for time dependent vaporization rate measurements.

The group at Chalmers University has used this technique to study $\mathrm{Cr}$ vaporization rates from a variety of ferritic stainless steels with and without barrier coatings. They demonstrated the effectiveness of Cobalt coatings on Sanergy HT, by measuring an order of magnitude reduction in the $\mathrm{Cr}$ vaporization rate from coated samples. The reduced vaporization rate was attributed to the formation of Co-Mn-spinels. TEM bright field data from this work provide exceptionally highresolution images of surface spinel and oxide layers. ${ }^{56}$ Additionally, the group determined that $\mathrm{E}$-Brite exhibits greater $\mathrm{Cr}$ vaporization than Crofer 22 APU, ZMG 232 and Sanergy HT, which is a trend found throughout the literature (see Table III). E-Brite contains substantially less $\mathrm{Mn}$ than the other alloys, inhibiting the formation of an additional passivating $(\mathrm{Cr}, \mathrm{Mn})_{3} \mathrm{O}_{4}$ spinel layer on top of the $\mathrm{Cr}_{2} \mathrm{O}_{3}$ layer. $\mathrm{Cr}$ vaporization rates from Crofer 22 APU, Sanergy HT, and E-Brite determined with the denuder technique are among the highest values reported in the literature.

Ionic conductivity method.- The ionic conductivity method (ICM) is a variation of the traditional transpiration technique where exhaust gases are bubbled though a de-ionized water bath. $\mathrm{Cr}$ vapors are removed from the effluent gas flow, since $\mathrm{CrO}_{2}(\mathrm{OH})_{2}$ and $\mathrm{CrO}_{3}$ are soluble in water up to $1.68 \mathrm{~kg} / \mathrm{L} .{ }^{16}$ The resulting solution becomes conductive due to the presence of chromium-based anions, where conductivity is directly related to the amount of $\mathrm{Cr}$ collected. System calibration is required and can be achieved by measuring the conductivity of solutions with known $\mathrm{Cr}$ concentrations. ICM makes it possible to quantify $\mathrm{Cr}$ vaporization rates and is the only technique available for continuous, time-resolved vaporization studies.

Complications can arise when ions other than $\mathrm{Cr}$ are collected, since the conductivity measurement does not distinguish between 


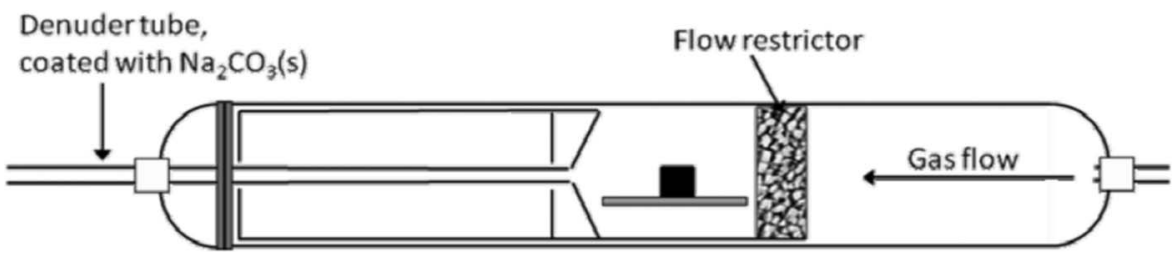

Figure 12. Simplified schematic of the denuder technique. ${ }^{4}$

different ionic species. For example, fused quartz reactors and $\mathrm{Si}$ based flow restrictors, commonly employed in the transpiration method, are well known to generate $\mathrm{Si}$ vapors in humid oxidizing environments at $800^{\circ} \mathrm{C} .{ }^{35} \mathrm{Casteel}$, et al. evaluated the conductivity of an empty reaction chamber in order to establish a baseline. They observed through ICP-MS analysis that $\mathrm{Si}$ ions were present in the collected solution. Conductivities from $\mathrm{Cr}$ and $\mathrm{Si}$ sources were successfully separated through baseline experiments, demonstrating that, when used in parallel with ICP-MS, the ionic conductivity method provides a real-time measure of $\mathrm{Cr}$ vaporization. However, vaporization rates found using ICM tend to be at the low end of the spectrum when compared to other investigators, especially considering the high water vapor pressures used during experimentation.

\section{Conclusions}

The transpiration method remains as one of the most effective ways to quantify a vapor evolving from a solid when large quantities of other gases persist in the gaseous environment. For this reason, reactive $\mathrm{Cr}$ vaporization from ferritic steel alloys, coated alloys and chromia in oxidizing environments has been studied using the transpiration method. Recently, new $\mathrm{Cr}$ collection techniques have emerged that simplify the experimental process when compared to traditional condensation-based collectors. $\mathrm{Cr}$ vaporization rates are predominantly on the order of $10^{-10} \mathrm{~kg} \mathrm{~m}^{-2} \mathrm{~s}^{-1}$ for uncoated alloys, with the denuder and traditional condensation techniques reporting the highest vaporization rates. Variability between investigators can largely be attributed to differences in temperature, water vapor pressure, measurement duration, and $\mathrm{Cr}$ collection efficiency.

Many technologies will benefit from knowledge of $\mathrm{Cr}$ vaporization rates and equilibrium $\mathrm{Cr}$ vapor pressures. From the data compiled in this paper, continuity exists between different investigators examining the same alloys within similar chemical environments. Nevertheless, the equilibrium vapor pressure of $\mathrm{CrO}_{2}(\mathrm{OH})_{2}$ remains to be precisely defined by the scientific community. In order to improve current chemical databases and to aid in the development of advanced alloys continued transpiration-based investigations into $\mathrm{Cr}-\mathrm{O}-\mathrm{H}$ systems by the experimental community are a necessity.

\section{Acknowledgments}

Portions of this work were supported by a NASA-EPSCoR grant \#NNX09AP73A. Thank you to the faculty, researchers and staff at Montana State University's Image and Chemical Analysis Laboratory, Ion Beam Laboratory and the Environmental and Biofilm Mass Spectrometry Facility for their assistance and expertise.

\section{References}

1. Z. G. Yang, J. W. Stevenson, and P. Singh, Adv. Mater. Proc., 161, 34 (2003).

2. S. C. Singhal, Electrochem. Soc. Interface, 16, 41 (2007).

3. D. M. England, "A Metallic Interconnect for a Solid Oxide Fuel Cell Stack", Ph.D. Dissertation, Univ. Utah, Salt Lake City, UT (2001).

4. J. Froitzheim, H. Ravash, E. Larsson, L. G. Johansson, and J. E. Svensson, J. Elec trochem. Soc., 157, B1295 (2010).

5. D. Caplan and M. Cohen, J. Electrochem. Soc., 108, 438 (1961)

6. R. T. Grimley, R. P. Burns, and M. G. Inghram, J. Chem. Phys., 34, 664 (1961).

7. Y. W. Kim and G. R. Belton, Met. Trans., 5, 1811 (1974).

8. G. C. Fryburg, R. A. Miller, F. J. Kohl, and C. A. Stearns, J. Electrochem. Soc., 124, 1738 (1977).
9. H. Kurokawa, C. P. Jacobson, L. C. DeJonghe, and S. J. Visco, Solid State Ionics, 178, 287 (2007).

10. S. P. Jiang, Y. D. Zhen, S. Zhang, A. I. Y. Tok, and P. Wu, J. Electchem. Soc., 153, A2120 (2006)

11. S. Taniguchi, M. Kadowaki, H. Kawamura, T. Yasuo, Y. Akiyama, Y. Miyake, and T. Saitoh, J. Power Sources, 55, 73 (1995).

12. S. P. S. Badwal, R. Deler, K. Foger, Y. Ramprakash, and J. P. Zhang, Solid State Ionics, 99, 297 (1997).

13. M. Stanislowski, J. Froitzheim, L. Niewolak, W. J. Quadakkers, K. Hilpert, T. Markus, and L. Singheiser, J. Power Sources, 164, 578 (2007).

14. E. Konysheva, H. Penkalla, E. Wessel, J. Mertens, U. Seeling, L. Singheiser, and K. Hilpert, J. Electrochem. Soc., 153, A765 (2006).

15. M. Stanislowski, E. Wessel, K. Hilpert, T. Markus, and L. Singheiser, J. Electrochem. Soc., 154 (4) A295 (2007).

16. M. Casteel, D. Lewis, P. Wilson, and M. Alinger, Int. J. Hydrogen Energy, 37, 6818 (2012).

17. K. Alvarez, K. Sato, S. K. Hyun, and H. Nakajima, Mater. Sci. Eng., C, 28, 44 (2008).

18. I. Saeki, T. Saito, R. Furuichi, H. Konno, T. Nakamura, K. Mabuchi, and M. Itoh, Corros. Sci., 40, 1295 (1998).

19. R. Sachitanand, M. Sattari, J. E. Svensson, and J. Froitzheim, Int. J. Hydrogen Energy, 38, 15328 (2013).

20. S. P. Jiang, S. Zhang, and Y. D. Zhen, J. Mater. Res., 20, 747 (2005).

21. M. Krumpelt, T. A. Cruse, B. J. Ingram, J. L. Routbort, S. Wang, P. A Salvador, and G. Chen, J. Electchem. Soc., 157, B228 (2010).

22. C. Collins, J. Lucas, T. L. Buchanan, M. Kopczyk, A. Kayani, P. E. Gannon, M. C. Deibert, R. J. Smith, D. S. Choi, and V. I. Gorokhovsky, Surf. Coat. Technol., 201, 4467 (2006).

23. J. Froitzheim, E. Larsson, L. G. Johansson, and J. E. Svensson, ECS Trans., 25(2), 1423 (2009).

24. N. Yasuda, T. Uehara, M. Okamoto, C. Aoki, T. Ohno, and A. Toji, ECS Trans., 25(2), 1447 (2009)

25. U. Merten and W. E. Bell, The Characterization of High-Temperature Vapors, J. L. Margrave, Editor, p. 91, John Wiley \& Sons, New York, (1967).

26. M. Costa, Crit. Rev. Toxicol., 27, 431 (1997).

27. D. R. Stull and H. Prophet, The Characterization of High-Temperature Vapors, J. L. Margrave, Editor, p. 400, John Wiley \& Sons, New York, (1967).

28. M. A. V. Ribeiro da Silva, M. J. S. Monte, and L. M. N. B. F. Santos, J. Chem. Thermodyn., 38, 778 (2006)

29. P. G. Wahlbeck, High Temp. Sci., 21, 189 (1986).

30. M. C. Croarkin, W. F. Guthrie, G. W. Burns, M. Kaeser, and G. F. Strouse, Natl. Inst. Stand. Technol. Monograph, 175, 630 (1993).

31. C. Gindorf, L. Singheiser, and K. Hilpert, J. Phys. Chem. Solids, 66, 384 (2005).

32. E. J. Opila, N. S. Jacobson, D. L. Myers, and E. H. Copland, J. Mater, 58, 22 (2006).

33. P. Alnegren (Chalmers), private communication, (2013).

34. E. J. Opila, D. L. Myers, N. S. Jacobson, I. M. B. Nielsen, D. F. Johnson, J. K. Olminsky, and M. D. Allendorf, J. Phys. Chem. Solids A, 111, 1971 (2007).

35. N. Jacobson, D. Myers, E. Opila, and E. Copland, J. Phys. Chem. Solids, 66, 471 (2005).

36. R. Viswanahan, T. S. Lakshmi, and S. Nalini, J. Phys. Chem. B, 113, 8362 (2009).

37. F. D. Richardson and C. F. Alcock, Physicochemical Measurements at High Temperatures, J. O’M. Bockris, Editor, p. 135, Academic Press, New York (1959).

38. H. C. Graham and H. H. Davis: J. Amer. Ceram. Soc., 54, 89 (1971).

39. B. B. Ebbinghaus, Combust. Flame, 93, 119 (1993).

40. J. W. Fergus, Int. J. Hydrogen Energy, 32, 3664 (2007).

41. H. F. Windisch, J. F. Froitzheim, and J. E. Svensson, ECS Trans., 57(1), 2225 (2013).

42. K. Hilpert, D. Das, M. Miller, D. H. Peck, and R. Weiß, J. Electrochem. Soc., 143, 3642 (1996).

43. IVTANTHERMO for Windows, version 3.0, (1992-2003).

44. P. W. Gilles, The Characterization of High-Temperature Vapors; J. L. Margrave, Editor, p. 19, John Wiley \& Sons, Inc., New York, (1967).

45. The 30-Minute Guide to ICP-MS, PerkinElmer, Inc, (2001).

46. Y. K. Agrawal and K. R. Sharma, Talanta, 67, 112 (2005).

47. F. J. Perez-Trujillo and S. I. Castaneda, Oxid. Met., 66, 231 (2006).

48. J. Froitzheim, G. H. Meier, L. Niewolak, P. J. Ennis, H. Hattendorf, L. Singheiser, and W. J. Quadakkers, J. Power Sources, 178, 163 (2008).

49. D. Chatterjee and S. Biswas, Int. J. Hydrogen Energy 36, 4530 (2011).

50. MSU HT materials research group, unpublished work (2012). 
51. H. Chen, J. A. Lucas, W. Priyantha, M. Kopczyk, R. J. Smith, K. Lund, C. Key, M. Finsterbusch, P. E. Gannon, M. Deibert, V. I. Gorokhovsky, V. Shutthanandan, and P. Nachimuthu, Surf. Coat. Technol., 202, 4820 (2008).

52. J. G. Grolig, J. Froitzheim, and J-E. Svensson. J. Power Sources, 248, 1007 (2014)

53. Hawley's Condensed Chemical Dictionary, 13th ed., R. J. Lewis, Sr. Editor, p. 268, John Wiley \& Sons, New York, (1997).
54. P. G. Gormley and M. Kennedy, in Proceedings of the Royal Irish Academy. Section A: Mathematical and Physical Sciences, PV 52, p. 163, The Royal Irish Academy, Dublin, IR, (1949).

55. Z. Ali, C. L. Paul Thomas, and J. F. Alder, Analyst, 114, 759 (1989).

56. J. Froitzheim, S. Canovic, M. Nikumaa, R. Sachitanand, L. G. Johansson, and J. E. Svensson, J. Power Sources, 220, 217 (2012). 